\title{
Marketability and Workability of Public Institute of Higher Education Graduates From the Employers' Perspective
}

\author{
Muhammad Hussin, Randip Kaur Valdev Singh, Ng Yen Ching
}

To Link this Article: http://dx.doi.org/10.6007/IJARBSS/v11-i3/8986

DOI:10.6007/IJARBSS/v11-i3/8986

Received: 04 January 2021, Revised: 28 January 2021, Accepted: 20 February 2021

Published Online: 20 March 2021

In-Text Citation: (Hussin et al., 2021)

To Cite this Article: Hussin, M., Singh, R. K. V., \& Ching, N. Y. (2021). Marketability and Workability of Public Institute of Higher Education Graduates From the Employers' Perspective. International Journal of Academic Research in Business and Social Sciences, 11(3), 851-860.

Copyright: (c) 2021 The Author(s)

Published by Human Resource Management Academic Research Society (www.hrmars.com)

This article is published under the Creative Commons Attribution (CC BY 4.0) license. Anyone may reproduce, distribute, translate and create derivative works of this article (for both commercial and non-commercial purposes), subject to full attribution to the original publication and authors. The full terms of this license may be seen at: http://creativecommons.org/licences/by/4.0/legalcode

Vol. 11, No. 3, 2021, Pg. 851 - 860

Full Terms \& Conditions of access and use can be found at http://hrmars.com/index.php/pages/detail/publication-ethics 


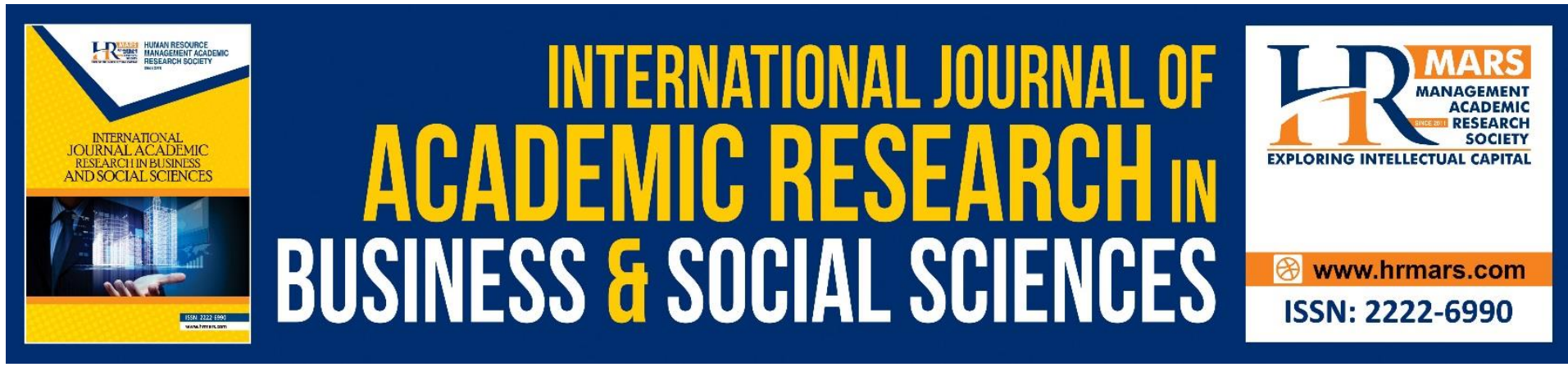

\title{
Marketability and Workability of Public Institute of Higher Education Graduates From the Employers' Perspective
}

\author{
Muhammad Hussin ${ }^{1}$, Randip Kaur Valdev Singh ${ }^{2}$, Ng Yen \\ Ching ${ }^{3}$ \\ Faculty of Education, Universiti Kebangsaan Malaysia \\ Email: ${ }^{1}$ banting99@hotmail.com, ${ }^{2}$ raenee79@yahoo.com, ${ }^{3}$ qtech.management@gmail.com
}

\begin{abstract}
This study aims to examine the perception of employers on the marketability and workability of Public Institute of Higher Education graduates. The study sample consists of 50 employers, both from natives and non-natives from the state of Selangor, Malaysia. Aspects that are researched in relation to the marketability include basic academic skills, high-level thinking skills and individual quality while the workability aspect is seen in terms of work planning and ability to perform work. The results of the study found that employers' perception of basic academic skills, individual quality and ability to perform are high. Yet, employers' perception is moderate towards high-level thinking and job planning. The study found that there was no significant difference between male and female employers as well the age of the employer on the marketability and workability of Public Institute of Higher Education graduates. However, the study found that there is a significant difference between the perceptions of service sector employers (in the government sector) and non-service sector employers (in the private sector) in terms of basic academic skills and job planning. The implications of the study and recommendations to improve the marketability and workability of Public Institute of Higher Education graduates are also discussed.
\end{abstract}

Keywords: Marketability, Workability, Public Institute of Higher Education, Graduates, Employers

\section{Introduction}

Socioeconomic development at this time requires institutions of higher education to produce graduates that are better suited to meet the demands of current economic development and have a variety of skill sets especially in terms of cognitive skills, social and communicative skills, competitiveness, self-confidence, analytical skills and so on. These skills will be the required elements that will increase the chances of the graduates to be employed (employability) and ability to work (workability) to meet the needs of employers, markets and society. 


\section{Statement of Problem}

Education is an instrument in the development of the country. Starting with one university in 1957, Malaysia now has around 600 institutes of higher education. The development of this education or investment in education is in line with economic development and technological advancement and this exceeds the demands of social and political factors.

In the early stages, indeed the goal of education was to meet the demands of cultural and social development. However, the focus has now shifted to provide manpower for national development. The ability to meet these requirements depends on the ability of the education system to create a match the graduate quality, especially in terms of cognitive skills, social and communication skills, competitiveness, confidence, analytic ability and so on with the demands of economic development at this time. In this context, as unemployed graduates are more likely to be native graduates, the question arises as to what are the real need in the employer sector?

Unemployment among graduates is often associated with their academic ability and mismatch in majoring. Most of these unemployed graduates are said to be focused on social science specialization. However, statistics from the Ministry of Human Resources show that graduates in the field of Information Technology and Engineering are also registering for unemployment, including high-achieving graduates. Thus, some view factors such as management and cognitive skills (related to academic ability) are not necessarily the main factors of choice within employers. This indicates that demands may have changed due to changes in the economy as well as changes in expectations and perceptions of employers and society. Given the huge investment in higher education, the question of the extent to which public universities have successfully met the expectations and goals of employers is important to assess as this is directly related to the ability or skills of Public Institute of Higher Education graduates to be employed and the ability to be trained. To meet this demand, it is important that employers' expectations to be understood.

\section{Purpose of the Study}

By examining the marketability and workability of Public Institute of Higher Education graduates, this study aims to examine the general perception of employers on the marketability and workability of graduates produced by Public Institute of Higher Education and identify factors that contribute to employability and workability among the graduates.

\section{Literature Review}

A study by the Secretary's Commission on Achieving Necessary Skills shows that more than half of the young people who leave educational institutions do not have the knowledge or foundation needed to find or hold a good position (Department of Labor, 1991). Most of the employers interviewed stated that graduates of educational institutions mostly lack skills in non-technical aspects. This study report explains that "Employers have no quarrel with the skills performance of today's graduates, but they do have serious reservations when it comes to their non-technical abilities".

Several studies have shown that most employers require employees with basic skills in addition to high-level skills and affective skills (Baxter \& Young, 1982; Buchanan, 1990; Packer, 1992; Rosove, 1982). However, most of these researchers identify the different skills required depending on the type of job. Although there are some differences in regards to the job scopes, overall, they agree that there are 3 aspects of skills or standard requirements that the employers seek, namely basic skills (communication, comprehension, skills, mathematics, 
writing), advances thinking skills (problem solving, learning skills, creative, innovative, and decision-making skills), and affective skills and traits (able to work without control, positive attitude toward work, punctuality and efficiency, interpersonal skills, teamwork and selfconfidence, positive self-image, adaptability, flexibility and enthusiasm, motivated, high selfdiscipline, self-management, neat, honestly and integrity and able to work without supervision) (Poole, 1985).

It should be emphasized that these three skills or 3R's have suitable applications for all three sectors of small, medium and large industries. Similarly, the concept of $3 R^{\prime} s$ is suitable for the government sector as well as the private sector. Poole $(1985$, p. 17) also asserts that "Specific occupational skills are less crucial for entry-level employment than a generally high-level of literacy, responsible attitudes toward work, the ability to communicate well, and the ability to continue to learn".

Charner (1988) has identified nine reasons that influence employer's selection, namely (i) low grade and poor academic achievement; (ii) negative attitude and lack of selfconfidence; (iii) has no goals and low motivation; (iv) no spirit and has low leadership potential; (v) no preparation for the interview; (iv) excessive salary claims and expectations; (vii) lack of preparation for work; (viii) lack of co-curricular activities; and (ix) low basic skills.

A study by Robinson (2001) shows that although the level of academic qualifications required to enter a job market is sometimes low, academic qualifications are still an important component in determining individual marketability. Meanwhile, Ramlee (2002) found that employers are satisfied with the technical skills of technical graduates in Malaysia but are unsatisfied with interpersonal skills, critical thinking, problem solving and entrepreneurial skills.

Based on some interviews and studies, it is clear that the needs of employers although not standard across the board, hold some similarities as asserted by Poole (1985). These skills can be learned directly or indirectly (Buck \& Barrick, 1987). Direct learning of skills usually takes place through the application of various generic skills and other skills in the teaching and learning process. Indirect learning, on the other hands, usually takes place through activities outside the lecture room, namely co-curricular activities. It is for these reasons that some views have emerged that indicate management factors and cognitive skills (related to academic ability) are not necessarily the primary factors that influence the choice of employers.

\section{Design and Sample Study}

In order to explore the employers' perception of the marketability and workability of Public Institute of Higher Education graduates, a quantitative study in the form of survey was conducted. Questionnaire method was used to collect data from respondents. Stratified random sampling was performed to obtain a sampling unit. A total of ten strata were used to obtain the sampling unit in this study. The sampling unit for each stratum is randomly selected from the sampling frame. The study population consisted of all employers in the private and government sectors, community leaders and individuals. The respondents of this study consisted of employees in the government and private sector; community leaders; as well as individuals. The study sample consists of $50 \mathrm{employers} \mathrm{from} \mathrm{natives} \mathrm{and} \mathrm{non-natives} \mathrm{from} \mathrm{the}$ state of Selangor. The employers of the study sample came from the service and non-service sectors. As this study is only conducted in the state of Selangor, the generation of findings is limited to this state only. 


\section{Study Instrument}

The self-constructed questionnaire in this study is related to the marketability and workability of Public Institute of Higher Education graduates. Among the aspects studied in the marketability of graduates are basic academic skills, high-level thinking skills and individual quality, while the aspect of workability is seen in terms of work planning and ability to perform work. Thus, the questionnaire in this study consists of 3 sections. Section A covers questions related to background information in relation to the demographic characteristics of the respondents, namely gender, race, age, and sector. Section B of the questionnaire is to measure the marketability level of Public Institute of Higher Education graduates which contains 30 items. Items 1 to 10 relate to the level of basic academic skills, items 11 to 21 are related to the level of high-level thinking skills and items for 21 to 30 are related to the level of individual quality. For Section C, 20 items are formed to measure the level of workability of Public Institute of Higher Education graduates. A total of 20 items outlined are relevant to work planning abilities and work execution abilities. Items 1 to 10 is to measure the level of work planning and items 11 to 21 is to measure the level of ability to perform work. These items were measured on a Likert scale. Each item has 5 answer choices that state the degree of agreement in the form of 5 points. The position of the scale is 1 (Strongly Disagree), 2 (Disagree), 3 (Very Disagree), 4 (Agree) and 5 (Strongly Disagree). Negative items were reencoded into positive form.

\section{Study Respondent Profile}

Respondents in this study consisted of 27 (54.0\%) male employers and 23 (46.0\%) female employers. A total of 29 (58.0\%) native employers and 21 (42.0\%) non-native employers. Among them, employers aged between 24 to 30 years are a minority group, which is 5 (10.0\%) compared to employers aged 31 to 40 years, who were a total of $22(44.0 \%)$ and employers 40 years and above a total of $23(46.0 \%)$. A total of $39(78.0 \%)$ employers are from the service sector and 11 (22.0\%) employers are from the non-service sector. The profile of the respondents are shown in Table 1 below.

Table 1

Sample Profile of Study Respondents

\begin{tabular}{llll}
\hline Variables & Profile & Frequency $(\mathbf{n})$ & Percentage (\%) \\
\hline Gender & Male & 27 & 54 \\
& Female & 23 & 46 \\
Race & Native & 29 & 58 \\
& Non-native & 21 & 42 \\
Age & $24-30$ years & 5 & \\
& $31-40$ years & 22 & 10 \\
& 40 years and above & 23 & 44 \\
& & & 46 \\
Sector & Service & 39 & 78 \\
& Non-service & 11 & 22 \\
\hline & & 50 & 100 \\
\hline
\end{tabular}




\section{Findings}

The findings of the study are described in the form of descriptive statistics and inferences to answer the questions and hypotheses of the study. To describe the overall level of marketability and workability of Public Institute of Higher Education graduates, the total mean is calculated and divided by the number of items to produce the overall mean. It was found that the mean score for the employer's perception scale on basic academic skills, individual quality and ability to perform work is high. The mean scores for basic academic skills were $\mu=3.67(s p=.62)$, individual quality $\mu=3.71(s p=.67)$, and ability to perform work $\mu=3.69$ ( $s p=.66$ ). However, employers' perception is moderate towards high-level thinking and graduate work planning, with the mean scores $\mu=3.57(s p=.69)$ and $\mu=3.58 \quad(s p=.65)$ respectively. The mean score is as shown in Table 2.

Although the mean differences shown is small, but this indicates that the aspect of individual quality is more dominant. Both aspects of high-level thinking and work planning are at a moderate level. This shows that efforts need to be made to produce graduates with highlevel thinking skills, namely to be able to argue based on empirical data, make accurate decisions in critical times, and perform task systematically. In addition, graduate's work planning abilities should also be improved. Employers need graduates who can allocate resources efficiently, make accurate expectations and have an effective emergency action plan.

\section{Table 2}

Mean Distribution Level of Basic Academic Skills, High-Level Thinking Individual Quality, Work Planning, and Ability to Perform Work

\begin{tabular}{lcc}
\hline Factor & Mean & Standard Deviation \\
\hline Marketability & & \\
Basic academic skills & 3.67 & .62034 \\
High-level thinking skills & 3.57 & .69018 \\
Individual quality & 3.71 & .67196 \\
& & \\
Workability & & \\
Work planning & 3.58 & .64924 \\
Ability to perform work & 3.69 & .65771 \\
\hline
\end{tabular}

Next, data analysis using t-test was performed to see the differences in employers' perception of marketability and workability of Public Institute of Higher Education graduates by gender, race, and sector. Based on Table 3 , it is found that the t-value for the comparison of employers' perception of the marketability and workability of Public Institute of Higher Education graduates based on gender is $t=.280$ and the significance level is $p=.781$. This significance level is greater than the 0.05 level. Therefore, the null hypothesis is accepted. Therefore, there is no significance difference in employers' perception of marketability and workability between male and female graduates. However, the mean score of male graduates $(\mu=3.67)$ was slightly higher than the female graduates $(\mu=3.62)$. This means that the level of marketability and workability of male graduates is higher compared to female graduates.

In addition, the results of the study also show that the t-value is $t=1.602$ and $p=.116$ for employers' perception of marketability and workability Public Institute of Higher Education graduates based on race. The value is above the significant level, which is 0.05 . Thus, there is no significant mean difference for employers' perception of marketability to 
work between native graduates and non-native graduates. Therefore, the null hypothesis is accepted. However, the mean score of native graduates $(\mu=3.76)$ is higher than non-native graduates $(\mu=3.49)$. This means that the marketability of Public Institute of Higher Education graduates is higher compared to non-native graduates.

Meanwhile, it was found that the results showed significant difference in the marketability and workability of Public Institute of Higher Education graduates by sector, namely, $t=2.135$ and $p<0.05$. The significance value is smaller than the set significance level. Thus, there is a significance difference in mean for marketability and workability between Public Institute of Higher Education graduates in both government and private sectors. Therefore, the null hypothesis is rejected. It was also found that the mean score of government $(\mu=3.74)$ was higher than that the private graduates $(\mu=3.32)$. This means the marketability and workability of government graduates is higher than that of private graduates.

\section{Table 3}

T-Test Analysis of Marketability and Employment Ability Differences of Public Institute of Higher Education Graduates by Gender, Race, and Sector

\begin{tabular}{llllll}
\hline Variables & Profiles & Number $(\mathbf{N})$ & Min $(\boldsymbol{\mu})$ & t-value & Significant $(\boldsymbol{p})$ \\
\hline Gender & Male & 27 & 3.67 & .280 & .781 \\
& Female & 23 & 3.62 & & \\
\multirow{4}{*}{ Race } & Native & 29 & 3.76 & 1.602 & .116 \\
& Non-native & 21 & 3.49 & & \\
\multirow{2}{*}{ Sector } & Government & 39 & & & \\
& Private & 11 & 3.74 & 2.135 & .038 \\
& & 3.32 & & \\
\hline
\end{tabular}

*Significant at 0.05 (2-end) confident level

Based on Table 4, the results of one-way ANOVA show the value of $F(37,81)=1.285$ and $p=.286$ for employers' perceptions of marketability and workability of Public Institute of Higher Education graduates. This means that there is no significant difference between graduates of different races according to the perceptions of employers. 
Table 4

One-Way ANOVA Analysis for Difference in Marketability and Workability by Race

\begin{tabular}{|c|c|c|c|c|}
\hline Factor & Causing Variation & Degree of Freedom $(d f)$ & Value & Significant $(p)$ \\
\hline Basic & Between Groups & 2 & 2.607 & .084 \\
\hline Academic & Intergroup & 2 & & \\
\hline Skill & Total & 4 & & \\
\hline High-level & Between Groups & 2 & .991 & .379 \\
\hline Thinking & Intergroups & 2 & & \\
\hline Skill & Total & 4 & & \\
\hline Individual & Between Groups & 2 & 2.082 & .136 \\
\hline \multirow[t]{2}{*}{ Quality } & Intergroups & 2 & & \\
\hline & Total & 4 & & \\
\hline Work & Between Groups & 2 & .048 & .953 \\
\hline \multirow[t]{2}{*}{ Planning } & Intergroups & 2 & & \\
\hline & Total & 4 & & \\
\hline Work & Between Groups & 2 & 1.906 & .160 \\
\hline \multirow[t]{2}{*}{ Impementation } & Intergroups & 2 & & \\
\hline & Total & 4 & & \\
\hline Total & & & 1.285 & .286 \\
\hline
\end{tabular}

*Significant confidence level at 0.05 (2-end)

\section{Discussion}

A study by Robinson (2001) shows that although the level of qualification required to enter a job market is sometimes low, basic academic skills are still the most important component to determine the marketability of Public Institute of Higher Education graduates.

In addition to academic qualifications to ensure the marketability of graduates, highlevel thinking skills are also very important. The ability to think, reason, and make decisions are essential for an employee to thrive and move forward. A person who can think critically, act logically and evaluate situations to make decisions and solve a problem, is an important and valuable asset to his employer.

Individual quality is important in being an indicator of the marketability of graduates because without individual quality, it is difficult for employers to use employees effectively to perform a task. Employees who have individual qualities have a high-level of confidence in themselves and are able to consult with other individuals effectively and openly while showing respect for themselves and others. Employees who have individual qualities feel that they are a part of the organization of the place they work and this makes them individuals who are positive about the career and organization in which they work.

Failure to equip the younger generation of graduates with employability skills is the same as failing to market these graduates or the younger generation to be effective employees of the organization in which they work. However, this can be overcomed in several ways. Employability skills that can be taught both at the school and in employee training. The purpose and objective of teaching these skills need to be determined in advance before being 
taught. Modules need to be designed to ensure that the purpose and objective of teaching these work skills are achieved.

In addition, parents need to be involved in determining employability skills and be a model since school level. Next, the working skills should be taught using a democratic approach so that the students' awareness of the values, attitudes and responsibilities of work increases. In addition, supervisors, coaches and teachers need to set a good example of the values they want to cultivate. Students should be given the opportunity to observe and understand the working skills required when entering the job market. Furthermore, when necessary, the circumstances of the place of study should reflect the actual circumstances of the workplace. Moreover, set high expectations of students for work skills they need. Not only that, teach and not tell. The duties of teachers and coaches become more effective if they carry out their duties as facilitators, that is, by being an example to the students.

One important thing that makes a person successful in a career is to have good academic level as well as high-level thinking skills. The ability to think and make decisions will make an employee have added value. For an employer, an employee who can think critically, act logically and evaluate situations to make decisions and solve problems is considered an important asset for an organization.

In addition to the above advantages, an employee has added value if he has the ability to think using the latest technology such as computers and other high-tech equipment. Apart from academic level and thinking ability, interpersonal skills are also an important foundation in the working world. Someone who has interpersonal skills has self-confidence and can deal with others honestly and openly. This will cause the employee to be respected by subordinates as well as superiors.

\section{Conclusion}

This study aims to examine the perception of employers on the marketability and workability of Public Institute of Higher Education graduates. Five constructs have been studied in surveying the marketablity and workablity of Public Institute of Higher Education graduates from the perception of employers. Aspects that are researched in relation to the marketability include basic academic skills, high-level thinking skills and individual quality while the workability aspect is seen in terms of work planning and ability to perform work.

The results shows that employers' perception of basic academic skills, individual quality and ability to perform are high. However, despite this finding, employers' perception is moderate towards high-level thinking and job planning. This shows there are other variables besides academic that need to be address such as employee generic skills, creativity, ability to solve problems etc. Generic skills are important because jobs today require flexibility, initiative and the ability to undertake many different tasks. They are not as narrowly prescribed and defined as in the past and generally they are more service oriented, making information and social skills increasingly important.

\section{References}

Baxter, M. B., \& Young, J. L. (1982). What do employers expect from high school graduates? NASSP Bulletin, 66(458), 93-98.

Buchanan, J. (1990). Ready for work, a call to action. Anchorage, AK: Alaska's Youth.

Buck, L. L., \& Barrick, R. K. (1987). They're trained, but are they employable? Vocational Education Journal, 62(5), 29-31.

Charner. (1988). Traning, task flexibility and low-skilled workers' employability. 
Department of Labor. (1991). What Work Requires of Schools. A SCANS Report for America 2000. Washington, DC: U.S Department of Labor.

Packer, A. H. (1992). Taking action on the SCANS report. Educational Leadership, 49(6), 27-31. Poole, V. A. (1985). Work experience programs can help develop human relations skills. Business Education Forum, 39, 9-10.

Ramlee. (2002). The role of vocational and technical education in the industrialization of Malaysia as perceived by educators and employers. (Unpublished doctoral dissertation). Purdue University.

Robinson, J. P. (2001). Workplace skills needed by today's workers. Alabama Cooperative Extension System, 2(6).

Rosove, B. (1982). Employability assessment: its importance and one method of doing it. Journal of Employment Counseling, 19(3), 113-123. 